\title{
PENGARUH KONSENTRASI GARAM DAN LAMA FERMENTASI TERHADAP KADAR PROTEIN BAKASANG LAOR
}

\author{
Calvin Talakua ${ }^{1)}$, Yuliana Rumengan ${ }^{2)}$ \\ ${ }^{1) 2)}$ Jurusan MIPA STKIP Gotong Royong Masohi \\ email $^{1)}$ : talakua_calvin@yahoo.co.id
}

\begin{abstract}
ABSTRAK: Laor merupakan koloni cacing yang muncul di permukaan laut untuk berkembang biak pada waktu tertentu. Di Maluku, laor biasanya diolah menjadi bakasang. Pada proses pembuatan bakasang, laor asin kemudian disimpan dalam botol selama waktu tertentu. Tujuan penggaraman adalah untuk meningkatkan umur simpan bakasang laor. Secara kimiawi penggaraman berfungsi untuk mengontrol pertumbuhan organisme, membentuk tekstur yang diinginkan, dan menghambat pertumbuhan organisme patogen. Penggaraman dan lama fermentasi merupakan faktor penting dalam proses fermentasi bakasang. Penggaraman dan lama fermentasi dapat mempengaruhi kandungan protein laor bakasang. Garam dapat meningkatkan tekanan osmotik substrat, menyebabkan penarikan air dalam makanan, dan dapat menyebabkan denaturasi protein. Saat ini masyarakat Maluku belum memiliki informasi mengenai kadar garam dan waktu fermentasi terbaik untuk menghasilkan bakasang laor dengan kandungan protein yang tinggi, yang sesuai dengan standar gizi yang dibutuhkan oleh tubuh. Penelitian ini bertujuan untuk mengetahui pengaruh konsentrasi garam dan lama fermentasi terhadap kandungan protein laor bakasang. Jenis penelitian ini adalah penelitian eksperimental dengan rancangan acak kelompok, menggunakan kombinasi konsentrasi garam dan lama fermentasi. Hasil penelitian menunjukkan kadar protein tertinggi yaitu 13,78 dihasilkan dari perlakuan A1B1 (konsentrasi garam 10\% dan lama fermentasi 10 hari). Sedangkan kadar protein terendah pada perlakuan A3B3 (konsentrasi garam 30\% dan lama fermentasi 30 hari) dengan kadar protein 10,32 . Selanjutnya berdasarkan hasil analisis varians diperoleh nilai $F$ lebih tinggi dari $\mathrm{F}$ tabel pada taraf 0,05 dan 0,01. Dengan demikian, perlakuan penggaraman dan lama fermentasi berpengaruh nyata terhadap kandungan protein laor bakasang. Selanjutnya bagi masyarakat yang mengolah bakasang laor disarankan untuk tidak melakukan penggaraman dengan konsentrasi tinggi terlalu lama agar kandungan protein pada bakasang laor dapat tetap terjaga.
\end{abstract}

\section{Kata Kunci: Bakasang Laor, Konsentrasi Garam, Waktu Fermentasi, Protein}

ABSTRACT: Laor is a colony of worms that appear on the surface of the sea to reproduce at a certain time. In Maluku, laor is usually processed into bakasang. In the process of making bakasang, salted laor is then stored in a bottle for a certain time. The purpose of salting is to increase the shelf life of bakasang laor. Chemically, salting functions to control the growth of organisms, form the desired texture, and inhibit the growth of pathogenic organisms. Salting and fermentation time are important factors in the bakasang fermentation process. Salting and fermentation time can affect the protein content of bakasang laor. Salt can increase the osmotic pressure of the substrate, cause water withdrawal in food, and can lead to protein denaturation. Currently, the people of Maluku do not have information regarding the salt concentration and the best fermentation time to produce bakasang laor with high protein content, which is in accordance with the nutritional standards needed by the body. This study aim to determine the effect of salt concentration and fermentation time on the protein content of bakasang laor. This type of 
research is an experimental research with a randomized block design, using a combination of salt concentration and fermentation time. The results showed the highest protein content of 13.78 resulted from AlB1 treatment (10\% salt concentration and 10 days fermentation time). While the lowest protein content was in the A3B3 treatment (30\% salt concentration and 30 days fermentation time) with a protein content of 10.32. Furthermore, based on the results of the analysis of variance, the F-value is higher than the F-table at the 0.05 and 0.01 levels is obtained. Thus, the salting treatment and fermentation time had a significant effect on the protein content of bakasang laor. Furthermore, for people who process bakasang laor, it is advisable not to do salting with high concentrations for too long so that the protein content of bakasang laor can be maintained.

\section{Keywords: Bakasang Laor, Salt Concentration, Fermentation Time, Protein}

\section{PENDAHULUAN}

Secara astonomis, provinsi Maluku terletak antara $3^{\circ}$ LU-9 ${ }^{\circ}$ LS dan $124^{\circ}-136^{\circ}$ BT. Panjang garis pantai di provinsi Maluku mencapai 10.630,1 km dan menyimpan potensi kekayaan alam yang besar.

Salah satu potensi kekayaan laut yang cukup dikenal oleh masyarakat Maluku adalah Laor. Laor (Polychaeta) pertama kali diteliti Horst $(1904,1905)$ sebagai cacing khas perairan Maluku, Lysidice oele (Eunicidae). Spesies ini hanya muncul berkerumun di permukaan air pada bulanbulan tertentu ketika malam purnama atau beberapa hari setelahnya untuk melakukan perkawinan secara eksternal (Pamungkas, 2009). Saat itulah masyarakat Maluku melakukan proses penyidukan laor secara tradisional menggunakan alat tangkap khusus yang disebut Siru-siru.

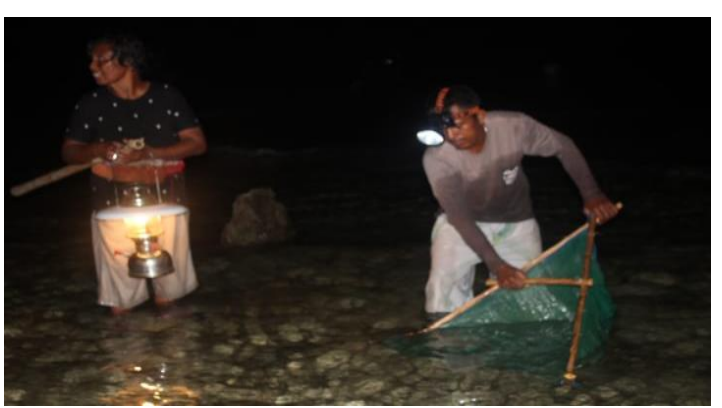

Gambar 1. Proses penyidukan laor di Maluku menggunakan Siru-siru

Sejak dulu, cacing laor telah diolah menjadi makanan atau masakan yang lezat secara tradisional di Maluku. Menurut Radjawane (1987), laor mempunyai nilai gizi yang tinggi, sebagai sumber kalori, dengan kandungan protein yang cukup tinggi sehingga dapat diandalkan sebagai bahan pangan fungsional untuk peningkatan gizi masyarakat.

Pada umumnya laor diolah menjadi bakasang. Bakasang merupakan pangan tradisional yang biasa dikonsumsi oleh masyarakat Maluku. Bakasang umumnya dibuat dari jeroan ikan yang difermentasi dalam wadah tertutup. Proses pengolahan bakasang laor dilakukan secara tradisional dengan bahan baku utama garam dan disimpan dengan jangka waktu tertentu. Garam memiliki fungsi untuk mengikat air dan memberi rasa yang sedap, selain itu pertumbuhan mikroorganisme yang tidak dikehendaki dapat dihambat dengan adanya garam. Pada umumnya bekteri pembusuk relatif lebih sensitif terhadap garam. Garam dapat berfungsi sebagai bahan pengawet karena dapat menaikan tekanan osmosis yang menyebabakan terjadinya plasmolysis pada sel mikroba (Purwangsih et.al., 2012). Waktu yang dibutuhkan untuk melakukan fermentasi bakasang umumnya sangat bervariasi tergantung pada selera masyarakat. Bakasang yang difermentasi dalam waktu lama akan memiliki cita rasa khas karena peranan asam laktat yang dihasilkan Lactobacilus yang tumbuh pada bakasang (Gunena, 2011). Selain memberi cita rasa, aktifitas Lactobacillus selama fermentasi dapat menghambat pertumbuhan mikroba kontaminan lain karena dapat menurunkan $\mathrm{pH}$. Namun seiring dengan penurunan $\mathrm{pH}$ menyebabkan terjadinya denaturasi protein. 
Pengujian kandungan protein bakasang laor selama waktu fermentasi tertentu diperlukan karena bakasang laor telah menjadi makanan favorit masyarakat Maluku, namun masyarakat kurang memiliki pengetahuan tentang pengaruh kadar garam dan waktu penyimpanan terhadap kualitas gizi bakasang laor yang dikonsumsi. Pengetahuan ini penting untuk mengedukasi masyarakat tentang kualitas bakasang laor setelah disimpan dalam kurun waktu tertentu.

\section{METODE PENELITIAN}

Jenis penelitian ini adalah penelitian eksperimen dengan menggunakan rancangan acak kelompok, yang terdiri dari kombinasi tiga perlakuan kadar garam dan tiga perlakuan lama fermentasi. Variabel dalam penelitian ini adalah variabel bebas yaitu konsentrasi kadar garam (100 g, 200 $\mathrm{g}$, dan $300 \mathrm{~g}$ ) dan lama fermentasi (10 hari, 20 hari dan 30 hari), serta variabel terikat yaitu kadar protein bakasang laor.

Selanjutnya alat dan bahan yang digunakan dalam penelitian ini disajikan pada tabel 1 dan tabel 2 dibawah ini.

Tabel 1. Alat-alat yang digunakan dalam penelitian

\begin{tabular}{clll}
\hline No & \multicolumn{1}{c}{ Alat } & \multicolumn{1}{c}{ Fungsi } \\
\hline $\mathbf{1}$ & $\begin{array}{l}\text { Lumpang dan } \\
\text { porselin }\end{array}$ & Menghaluskan sampel \\
\hline $\mathbf{2}$ & $\begin{array}{l}1 \quad \text { set alat } \\
\text { destilasi nitrogen }\end{array}$ & Melakukan destilasi \\
\hline $\mathbf{3}$ & Buret dan statik & Melakukan titrasi \\
\hline $\mathbf{4}$ & $\begin{array}{l}\text { Timbangan } \\
\text { analitik }\end{array}$ & Menimbang sampel \\
\hline $\mathbf{5}$ & Alat destruksi & $\begin{array}{l}\text { Menghancurkan zat-zat } \\
\text { lain yang terdapat } \\
\text { bersama dalam sampel }\end{array}$ \\
\hline $\mathbf{6}$ & Pipet tetes & $\begin{array}{l}\text { Meneteskan indikator } \\
\text { Dokumentasi kegiatan } \\
\text { penelitian }\end{array}$ \\
\hline $\mathbf{7}$ & Kamera & \multicolumn{2}{c}{} \\
& & &
\end{tabular}

Tabel 2. Bahan-bahan yang digunakan dalam penelitian

\begin{tabular}{|c|c|c|}
\hline No & Bahan & Fungsi \\
\hline 1 & Bakasang laor & Sebagai bahan analisis \\
\hline 2 & Asam sulfat & Menghidrolisis sampel \\
\hline
\end{tabular}

\begin{tabular}{cll}
\hline \multicolumn{3}{c}{ pekat 95-97\% } \\
\hline $\mathbf{3}$ & Natrium sulfat & Katalisator \\
\hline $\mathbf{4}$ & $\begin{array}{l}\text { Natrium } \\
\text { hidroksida } \\
45 \%\end{array}$ & $\begin{array}{l}\text { Membebaskan gas amoniak } \\
\text { dari larutan }\end{array}$ \\
\hline $\mathbf{5}$ & Asam boric 5\% & $\begin{array}{l}\text { Mengikat Nitrogen pada } \\
\text { saat destilasi }\end{array}$ \\
\hline $\mathbf{6}$ & $\begin{array}{l}\text { Indikator } \\
\text { (kertas lakmus) }\end{array}$ & $\begin{array}{l}\text { Petunjuk ekivalen pada saat } \\
\text { titrasi hasil destilasi }\end{array}$ \\
\hline $\mathbf{7}$ & $\begin{array}{l}\text { Asam klorida } \\
\text { 0,1 N }\end{array}$ & Menetralkan amoniak \\
\hline $\mathbf{8}$ & Mercury Oxide & Katalis/mempercepat reaksi \\
\hline $\mathbf{9}$ & Aquades & Pelarut \\
\hline
\end{tabular}

Prosedur pengumpulan data terdiri dari tahap pembuatan bakasang laor dan tahap uji kadar protein bakasang laor. Proses pembuatan bakasang laor diadopsi dari proses pembuatan bakasang laor secara tradisional oleh masyarakat desa Amahai berikut:

1. Laor dicuci di dalam wadah, selanjutnya ditiris dengan ayakan untuk memisahkan debu atau pasir

2. Laor ditimbang, selanjutnya diberi jeruk nipis dan garam dapur dengan jumlah sesuai dengan perlakuan

3. Laor dimasukan dalam botol kaca dan disimpan selama waktu sesuai dengan perlakuan

Selanjutnya untuk menghitung kadar protein Nitrogen digunakan rumus:

$$
\% \mathrm{~N}=\frac{m l H C L \text { sampel } x N H C L \times 14,008}{\text { gram sampel } X 1000} \times 100 \%
$$

Keterangan:

$\mathrm{mL} \mathrm{HCl}=$ vol $\mathrm{HCl}$ digunakan untuk titrasi

$\mathrm{N} \mathrm{HCl}=$ normalitas $\mathrm{HCl}(0,1 \mathrm{~N})$

$14,008=$ berat atom $\mathrm{N}$

Selanjutnya kadar protein dihitung menggunakan suatu faktor konversi. Besarnya faktor konversi $\mathrm{N}$ tergantung pada $\% \mathrm{~N}$ yang menyusun protein dalam suatu bahan.

$\%$ protein $=\% \mathrm{~N} \times$ faktor konversi $(6,25)$

Data penelitian ini terdiri dari data primer berupa data hasil analisis laboratorium, dan data sekunder berupa 
hasil kajian literatur yang relevan dengan rumusan masalah penelitian ini.

\section{HASIL DAN PEMBAHASAN}

Tabel 4 menyajikan data hasil analisis laboratorium kandungan protein bakasang laor dengan perlakuan variasi kadar garam dan waktu penyimpanan.

Tabel 4. Kandungan protein bakasang laor

\begin{tabular}{|c|c|c|c|c|c|c|}
\hline \multirow{2}{*}{$\begin{array}{c}\text { Kad } \\
\text { ar } \\
\text { gara } \\
\text { m }\end{array}$} & \multirow{2}{*}{$\begin{array}{c}\text { Lama } \\
\text { penyimpa } \\
\text { nan }\end{array}$} & \multicolumn{3}{|c|}{ Ulangan } & \multirow[t]{2}{*}{ TAB } & \multirow{2}{*}{$\begin{array}{c}\text { YA } \\
\text { B }\end{array}$} \\
\hline & & I & II & III & & \\
\hline A1 & B1 & $\begin{array}{c}13,6 \\
2\end{array}$ & $\begin{array}{c}13,4 \\
7\end{array}$ & $\begin{array}{c}14,2 \\
6\end{array}$ & $\begin{array}{c}41,3 \\
5\end{array}$ & $\begin{array}{l}13, \\
78\end{array}$ \\
\hline A2 & B2 & $\begin{array}{c}12,8 \\
7\end{array}$ & $\begin{array}{c}12,7 \\
1\end{array}$ & $\begin{array}{c}12,4 \\
4\end{array}$ & $\begin{array}{c}38,0 \\
2\end{array}$ & $\begin{array}{l}12, \\
67\end{array}$ \\
\hline A3 & B3 & $\begin{array}{c}11,4 \\
5\end{array}$ & $\begin{array}{c}12,1 \\
3\end{array}$ & $\begin{array}{c}12,5 \\
9\end{array}$ & $\begin{array}{c}36,1 \\
7\end{array}$ & $\begin{array}{l}12, \\
05\end{array}$ \\
\hline A2 & B1 & $\begin{array}{c}13,9 \\
7\end{array}$ & $\begin{array}{c}12,3 \\
1\end{array}$ & $\begin{array}{c}12,4 \\
6\end{array}$ & $\begin{array}{c}38,7 \\
4\end{array}$ & $\begin{array}{l}12, \\
91\end{array}$ \\
\hline & B2 & $\begin{array}{c}12,7 \\
4\end{array}$ & $\begin{array}{c}12,3 \\
2\end{array}$ & $\begin{array}{c}12,3 \\
0\end{array}$ & $\begin{array}{c}37,3 \\
6\end{array}$ & $\begin{array}{l}12, \\
45\end{array}$ \\
\hline & B3 & $\begin{array}{c}10,8 \\
2\end{array}$ & $\begin{array}{c}10,7 \\
9\end{array}$ & $\begin{array}{c}11,0 \\
7\end{array}$ & $\begin{array}{c}32,6 \\
8\end{array}$ & $\begin{array}{l}10, \\
89\end{array}$ \\
\hline A3 & B1 & $\begin{array}{c}11,5 \\
7\end{array}$ & $\begin{array}{c}11,7 \\
0\end{array}$ & $\begin{array}{c}12,1 \\
6\end{array}$ & $\begin{array}{c}35,4 \\
3\end{array}$ & $\begin{array}{l}11, \\
81\end{array}$ \\
\hline & B2 & 9,73 & $\begin{array}{c}11,0 \\
6\end{array}$ & $\begin{array}{c}10,3 \\
5\end{array}$ & $\begin{array}{c}31,1 \\
4\end{array}$ & $\begin{array}{l}10, \\
38\end{array}$ \\
\hline & B3 & $\begin{array}{c}10,0 \\
5\end{array}$ & $\begin{array}{c}10,1 \\
3\end{array}$ & $\begin{array}{c}10,4 \\
8\end{array}$ & $\begin{array}{c}30,6 \\
6\end{array}$ & $\begin{array}{l}10, \\
32\end{array}$ \\
\hline $\begin{array}{c}\text { Tota } \\
\mathbf{l}\end{array}$ & 106,82 & $\begin{array}{c}106 \\
72\end{array}$ & $\begin{array}{c}108, \\
11\end{array}$ & $\begin{array}{c}321 \\
55\end{array}$ & $\begin{array}{c}107 \\
16\end{array}$ & \\
\hline
\end{tabular}

Berdasarkan tabel 3 diatas, kandungan protein tertinggi yaitu 13,78 diperoleh dari bakasang laor yang difermentasi dengan kadar garam 10\% selama 10 hari $\left(\mathrm{A}_{1} \mathrm{~B}_{1}\right)$. Sementara kandungan protein terendah yaitu 10,32 diperoleh dari bakasang laor yang difermentasi dengan kadar garam 30\% selama 30 hari $\left(A_{3} B_{3}\right)$. Hubungan antara konsentrasi garam dan lamanya fermentasi dengan kandungan protein bakasang laor disajikan pada gambar 1 .

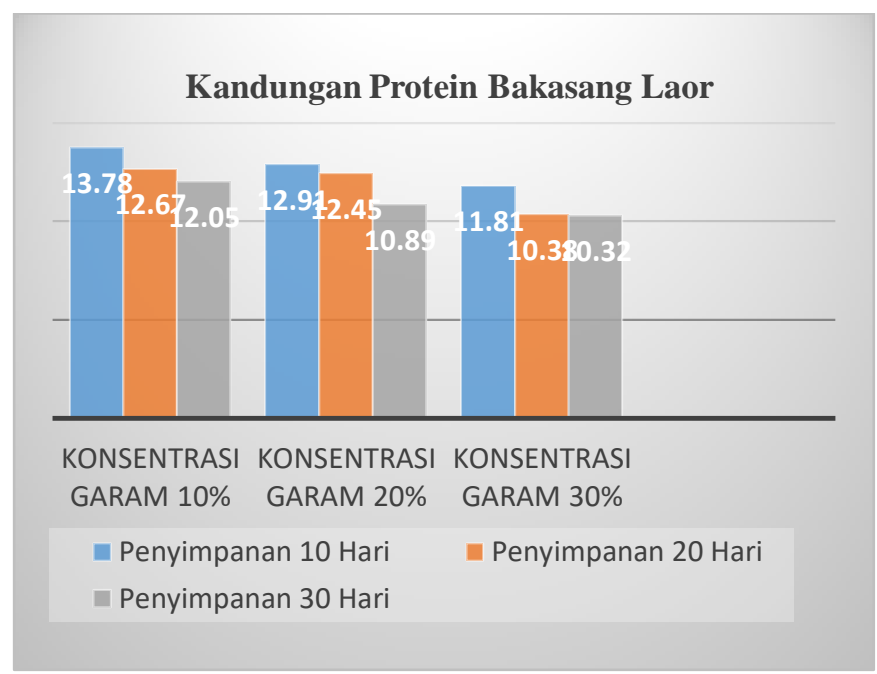

Gambar 1. Hasil analisis kandungan protein bakasang laor dengan variasi penambahan konsentrasi garam dan lama penyimpanan

Dari gambar 1 diatas, terlihat jelas bahwa seiring dengan bertambahnya konsentrasi garam dan lama fermentasi maka kandungan protein bakasang laor makin menurun.

Hasil perhitungan analisis varians diketahui bahwa nilai $\mathrm{F}$ hitung adalah $19,8>\mathrm{F}$ tabel 2,51 pada taraf signifikansi 0,05 dan 3,71 pada taraf signifikansi 0,01. Dengan demikian dapat disimpulkan bahwa kandungan protein bakasang laor dipengaruhi oleh variasi konsentrasi garam dan lama fermentasi.

Hasil uji Beda Nyata Terkecil (BNT) menunjukan bahwa terdapat perbedaan yang nyata antara kandungan protein bakasang laor yang diolah dengan variasi penambahan garam dan lama fermentasi. Artinya, variasi konsentrasi garam dan lama fermentasi memberikan perbedaan yang sangat nyata terhadap kandungan protein bakasang laor.

Berdasarkan sajian data penelitian dapat dilihat bahwa kandungan protein bakasang laor tertinggi $13,78 \%$ diperoleh dari hasil fermentasi menggunakan 
konsentrasi garam 10\% selama 10 hari. Hal ini dimungkinkan karena penggunaan $10 \%$ garam pada proses fermentasi bakasang laor masih berada pada batas toleransi. Kadar garam yang rendah justru makin menstabilkan struktur protein karena memungkinkan terjadinya interaksi hidrofobik. Seperti yang dijelaskan Andian dan Ichola (2008) bahwa garam akan menstabilkan protein pada konsentrasi rendah namun justru mendenaturasi protein pada konsentrasi tinggi. Selain kadar garam, waktu fermentasi juga mempengaruhi kandungan protein bakasang laor. Tingginya kandungan protein bakasang laor yang difermentasi selama 10 hari karena dalam waktu 10 hari molekul protein yang terdenaturasi belum banyak. Semakin lama waktu fermentasi semakin banyak protein yang terpecahkan (Safrulla, 2018).

Ditinjau dari tampilan fisiknya, bakasang laor yang difermentasi selama 10 hari paling baik untuk dikonsumsi. Semakin lama waktu fermentasi maka bakasang laor akan berair dan berbau busuk. Besarnya daya simpan dan kandungan protein bakasang laor tergantung dari seberapa besar kadar airnya. Semakin besar kadar air, maka semakin tidak awet dan makin kecil kandungan nutrisinya.

Di sisi lain, dengan bertambahnya konsentrasi garam dan waktu fermentasi maka kandungan protein bakasang laor makin menurun. Hasil penelitian menunjukan bahwa penggunaan konsentrasi garam 30\% selama 30 hari menurunkan kandungan protein bakasang laor hingga 10,32. Tingginya konsentrasi garam dan waktu fermentasi yang terlalu lama menurunkan kandungan protein karena terjadi interaksi antara garam dengan molekul-molekul organik protein. Interaksi yang terjadi menyebabkan denaturasi protein menjadi molekul-molekul yang lebih kecil. Maulidiyah et., al. (2020) menjelaskan bahwa denaturasi protein mengakibatkan membran sel rusak dan lisis karena adanya modifikasi pada struktur sekunder dan tersier. Sisi negatif yang diakibatkan proses denaturasi adalah protein kehilangan aktifitas biologis dan beberapa sifat fungsionalnya (Chayati, 2008).

Mekanisme reaksi yang mungkin terjadi dalam proses ini adalah pertama, pada lingkungan konsentrasi garam yang tinggi, ikatan-ikatan nonkovalen protein melemah sehingga terjadi pemecahan rantai molekul yang semula ikatannya kuat. Khamal (2013) menyatakan, jumlah protein yang terpecahkan sebanding dengan waktu fermentasi. Penjelasan ini dikuatkan oleh Anto (2019) yang menjelaskan bahwa semakin lama waktu fermentasi, maka semakin rendah pula daya molekul protein mengikat air. Laju dan besarnya nilai $\mathrm{pH}$ mempengaruhi daya ikat air tersebut, dimana semakin rendah $\mathrm{pH}$ lingkungan sekitar maka semakin rendah juga daya ikat air sehingga protein dapat mengalami denaturasi. Ketika pH lingkungan mencapai titik isoelektris maka protein akan mengalami kekeruhan tertinggi dan menggumpal, pada saat inilah protein akan terdenaturasi (Poedjiadi, 1994).

Kedua, pemutusan ikatan antara molekul-molekul protein yang selanjutnya membentuk ikatan non kovalen baru antara fraksi-fraksi protein itu sendiri menyebabkan struktur protein sedikit tertutup lagi karena fraksi-fraksi baru yang baru terbentuk lebih kecil dari molekulmolekul protein awal.

Kemungkinan lain terjadinya denaturasi protein disebabkan oleh tingginya tingkat keasaman bahan karena konsentrasi garam yang tinggi, sehingga menurunkan $\mathrm{pH}$. Setiap ion dari garam yang terionisasi akan berikatan dengan molekul-molekul air di sekitarnya (hidrasi ion) sehingga makin tinggi konsentrasi garam maka makin banyak molekulmolekul air yang diikat. Pamungkas (2009) menjelaskan bahwa terjadi proses osmosis selama proses penggaraman, yaitu garam 
yang berada di luar jaringan bahan akan menarik air di dalam jaringan bahan, sementara ion $\mathrm{Na}^{+}$dn $\mathrm{Cl}^{-}$akan masuk ke dalam jaringan bahan.

Syahrudin (2013) menjelaskan, dengan bertambahnya konsentrasi garam maka akan meningkatkan kelarutan protein, karena ion-ion anorganik garam yang terhidrasi sempurna akan mengikat permukaan protein sehingga mencegah agregasi molekul-molekul protein (salting in). Ion-ion garam akan cenderung mengikat air pada konsentrasi garam tinggi yang menyebabkan terjadinya penggabungan sehingga molekul-molekul protein akan mengendap (salting out).

Dalam proses pembuatan bakasang laor lazim digunakan garam dapur $(\mathrm{NaCl})$. Tingginya kadar garam menyebabkan berkurangnya jumlah air sehingga kadar air bakasang laor menjadi berkurang. Hal ini dapat menghambat pertumbuhan mikroorganisme yang tidak diinginkan sehingga bakasang laor yang dihasilkan lebih tahan lama.

Aktivitas mikroba-mikroba penghasil asam pada bakasang laor seperti Lactobacillus memberikan kontribusi pada cita rasa bakasang laor serta bersifat antimikroba. Metabolisme Lactobacillus menghasilkan asam laktat yang menurunkan $\mathrm{pH}$ bakasang laor sehingga menghambat pertumbuhan mikroba lain.

\section{KESIMPULAN}

Berdasarkan hasil penelitian dapat disimpulkan bahwa konsentrasi garam dan waktu fermentasi memberikan pengaruh sangat nyata terhadap kandungan protein bakasang laor. Kandungan protein tertinggi, 13,78 diperoleh dari fermentasi dengan konsentrasi garam 10\% selama 10 hari. Rekomendasi diberikan kepada masyarakat yang melakukan pengolahan bakasang laor agar tidak melakukan fermentasi terlalu lama dengan menggunakan konsentrasi garam terlalu tinggi, karena kandungan protein yang terkandung di dalamnya akan berkurang.

\section{REFERENSI}

Anto, A., Xyzquolyna, D., \& H. Ali, V. V. (2019). Sifat kimia dan mikrobiologi bakasang ikan oci (rastrelliger sp) dengan lama fermentasi yang berbeda. Pro Food, 5(1), 397. https://doi.org/10.29303/profood.v5i1. 94

Garwan, R. (2009). Perkembangan Histamin Selama Proses Fermentasi Dan Penyimpanan Produk Bakasang Jeroan Ikan Cakalang (Katsuwonus Pelamis, LIN). Sekolah Pascasarjana Institut Pertanian Bogor.

Gunena M. (2000). Karakteristik Biokimia Bakteri Kokus dan Basil Diisolasi dari Bakasang. Universitas Sam Ratulangi.

Joko Pamungkas. (2009). Pengamatan Jenis Cacing Laor (Annelida, Polychaeta) Di Perairan Desa Latuhalat Pulau Ambon, Dan Aspek Reproduksinya (Species Richness of Laor Worm (Annelida, Polychaeta) on Latuhalat Waters Ambon Island, and Its Reproduction Aspect). Jurnal TRITON, 5(2), 1 -10.

J., Pamungkas. (2015). Species richness and macronutrient content of wawo worms (Polychaeta, Annelida) from Ambonese water, Maluku, Indonesia. Biodiversty Data Journal, 3(2), 4251.

Khamal Dami, dkk (2013). Pengaruh Konsentrasi Garam Berbeda terhadap Mutu Ikan Tongkol (Euthynnus affinis) Asap. Jurnal Ilmiah Perikanan Dan Kelautan, 1(1).

Muhammad Asrullah, Ayu Hardianti Mathar, Citrakesumasarj, Nurhaedah Jafar, S. F. (2012). Denaturasi dan Daya Cernah Protein pada Proses Pengolahan Lawa Bale (Makanan 
Tradisional Sulawesi Selatan). Jurnal Media Gizi Masyarakat Indonesia., 2(3).

Ni'matul Maulidiyah, Hari Santoso, A. S. (2020). Analisis Perbandingan Kadar Protein Telur Itik (Khaki campbell) Sebelum dan Sesudah Perendaman dengan Jeruk Nipis (Citrus aurantifolia) pada Pengasinan (A Comparison Analysis of Protein Level of Duck Eggs (Khaki campbell) Before and After soaking with lim. EJurnal Ilmiah SAINS ALAMI, 2(2).

Nuruzzakiah, Rahmatan H, S. D. (2016).

Pengaruh Konsentrasi Garam Terhadap

Kadar Protein Dan Kualitas

Organoleptik Telur Bebek. Jurnal

Ilmiah Mahasiswa Pendidikan Biologi., 1(1).

Poedjiadi, A. (1994). Dasar-Dasar Biokimia. UI-Press.

Safrulla Amir, Saifuddin Sarajuddin, Nurhaedar Jafar, R. (2018). Pengaruh konsentrasi garam dan lama penyimpanan terhadap kandungan protein dan kadar garam telur asin. Jurnal Media Gizi Masyarakat Indonesia, 2(1).

Sintje Liline. (2017). Analisis Kadar Protein Cacing Laor (Polychaeta) dari perairan pulau Ambon. Biopendix., $3(2)$.

Sintje Liline, A. D. C. (2017). Identification of Laor Worms ( Polychaeta ) from the Sea Region of Haria Village of Central Maluku, Indonesia. International Journal of Science and Research Methodology, 7(1).

Syahruddin, H. (2013). Pegaruh Penggaraman terhadap Protein Ikan Layang ( Decapterus rucell). Jurnal
Imliah Masasiswa Universitas Surabaya( Calyptra), 1(2).

Tampubolon, K., Purnomo, D., \& Sangadji, M. (2007). Pengolahan pasta laor (.

Buletin Teknologi Hasil Perikanan, X, 47-58.

Winarno. (2008). Kimia Pangan dan Gizi. Edisi Terbaru. Gramedia Pustaka Utama. 